\title{
AZ ÚJ NEMZETI ATLASZBAN SZEREPLŐ FÖLDRAJZI TÁJBEOSZTÁS NEVEZÉKTANÁNAK ALAPELVEI
}

\author{
BASIC PRINCIPLES OF THE LANDSCAPE DIVISION IN THE NEW NATIONAL ATLAS OF HUNGARY
}

\section{CSORBA PÉTER}

Debreceni Egyetem, Földtudományi Intézet, Tájvédelmi és Környezetföldrajzi Tanszék

csorba.peter@science.unideb.hu

\begin{abstract}
Drawing the map of landscape division in the new National Atlas of Hungary, the authors followed two basic principles: 1) the hierarchy levels should adjust to the major regions of Europe and, if possible, to the taxonomic systems elaborated in the neighbouring countries; 2) landscape names and delineations should not be influenced by national borders. The former number of regions has been reduced from 35 to 31, but 6 'new' regions also appeared on the present territory of Hungary: the Fertö-Moson Plain, the Styrian Prealps, the Danubian (Váh-Nitra-Hron) Hills, the Alpine Foreland of the Rába (Raab), the Banat Plain and the Nógrád (Novohrad)-Abaúj (Abov) Depression. The microregions were affected by the most fundamental changes: instead of the former 230 microregions the new map of landscape divisions contains only 195 of them. More than $1 / 3$ of the names of the microregions have been modified, realizing a more consistent nomenclature. Among the microregion-groups and macroregions an almost forgotten historical name, the Vajdavár Region, reappears. Since in the case of many microregions the area beyond the national border, in a neighbouring country, is more extended, it seemed justified to employ the Hungarian versions of the official names used there (e.g. Németújvár/Güssing Hills, Losonc/Lučenec Basin). The authors tried to leave out hints to geomorphological features from the landscape names (e.g. floodplain, terrace, alluvial fan and others). In addition to the terminology, the alignment of landscape boundaries was also revised, but they were only modified where recent research led to considerable shift (at least 8-10 $\mathrm{km}$ ) in the boundaries.
\end{abstract}

Keywords: landscape taxonomy, harmonisation, historical names

\section{Bevezetés}

Az előző, 1989-ben megjelent nemzeti atlaszban szereplő táji nevezéktan elfogadottsága ellenére sem vált kizárólagos szereplöjévé a hazai tájbeosztási szakirodalomnak. Különösen erős volt a hiányérzet, ha valaki a teljes Kárpát-medence tájföldrajzi tagolása iránt érdeklődött. Az egységes Kárpát-medencei tájbeosztás kialakításának legismertebb hazai példája a Hajdú-Moharos József, Hevesi Attila és Horváth Zsolt által készített térkép volt (Hajdú-Moharos J. - Hevesi A. 1997). A szerzők következetesen változtattak olyan tájelnevezéseken, pl. Északi-középhegység, amelyben valamilyen égtáji irány szlovák, ukrán vagy román nézőpontból félrevezető lehet. Egyetlen kivétel a medence központjának kitüntetett helye, ami miatt a Dunántúl, illetve Tiszántúl 
megnevezéseket indokolt volt megtartani. Faragó Imre szintén egységes Kárpátmedencei magyar névhasználatra és számos régi magyar történelmi név feltámasztására törekedett (FARAGó I. 2014).

Harmadik nemzeti atlaszunk 2013-ban elkezdődött szerkesztési munkálatai során az új tájbeosztási, ún. taxonómiai nevezéktan (az atlasz „Tájak” fejezetének 19., 22. és 24. térképei) számára az alábbi alapelveket határoztunk meg:

- a politikai határok által szétvágott tájak elnevezésének egységesítése;

- a Kárpátokon belül eső tájak esetében a nemzeti hovatartozás elhagyása;

- a hierarchiaszintek hozzáillesztése a nagy európai természetföldrajzi egységekhez;

- a szomszéd országokban meglévő tájbeosztási szintek figyelembevétele.

\section{A legmagasabb rendszertani szintek}

Az egyes taxonómiai szintek topográfiai lehatárolását a legmagasabb tájrendszer (system) kategóriáknál kezdtük és a kistájak (small landscape unit) felé haladtunk (1. ábra). A térképen a tájbeosztási hierarchiaszintek a Kárpátokon túli területeken a nagytájrészletekig, a trianoni határokon kívüli egykori országrészek esetében pedig a középtáj taxonómiai szintig jelennek meg. Az Alsó-Duna-alföld, mint nagytáj esetében pl. a Románalföld és a Moesiai-alföld nagytájrészletek szerepelnek a térképen. Erdélyben viszont a Keleti-Kárpátok nagytáj és Külső-Keleti-Kárpátok nagytájrészleten belül a középtájak is felkerülnek a térképre, azaz ebben az esetben az Esztena-hegyvidék, a Beszterce-Tatroshegyvidék, a Háromszéki-havasok, a Bodzai-havasok, valamint a Brassói-havasok.

A térképi kivágatot, amely messze túlnyúlik a medencét körülvevő Kárpátokon, látható rajta a csehországi variszkuszi hegyvidéktől a Kelet-európai-síkvidékig és Dalmáciától Észak-Bulgáriáig terjedő tág terület, a Kárpát-medence helyett „KárpátPannon-térség” nevet kapott. A „pannon” megjelölést természetesen nem történelmi értelemben használjuk, hanem pl. a biogeográfiai szakirodalomban már jó ideje használt módon, vagyis az egész medencére kiterjesztve. A „Kárpát-Pannon-térség” megjelölést egyébként használta a Pannon Enciklopédia idézett kötetében a Hajdú-MoHaros J. Hevesi A. szerzőpáros is.

A hierarchiaszintek tekintetében igazodási kényszerben voltunk az osztrák, német, ill. szlovák nemzeti atlaszokban már évek óta szereplő magasabb, európai tájhierarchikus 


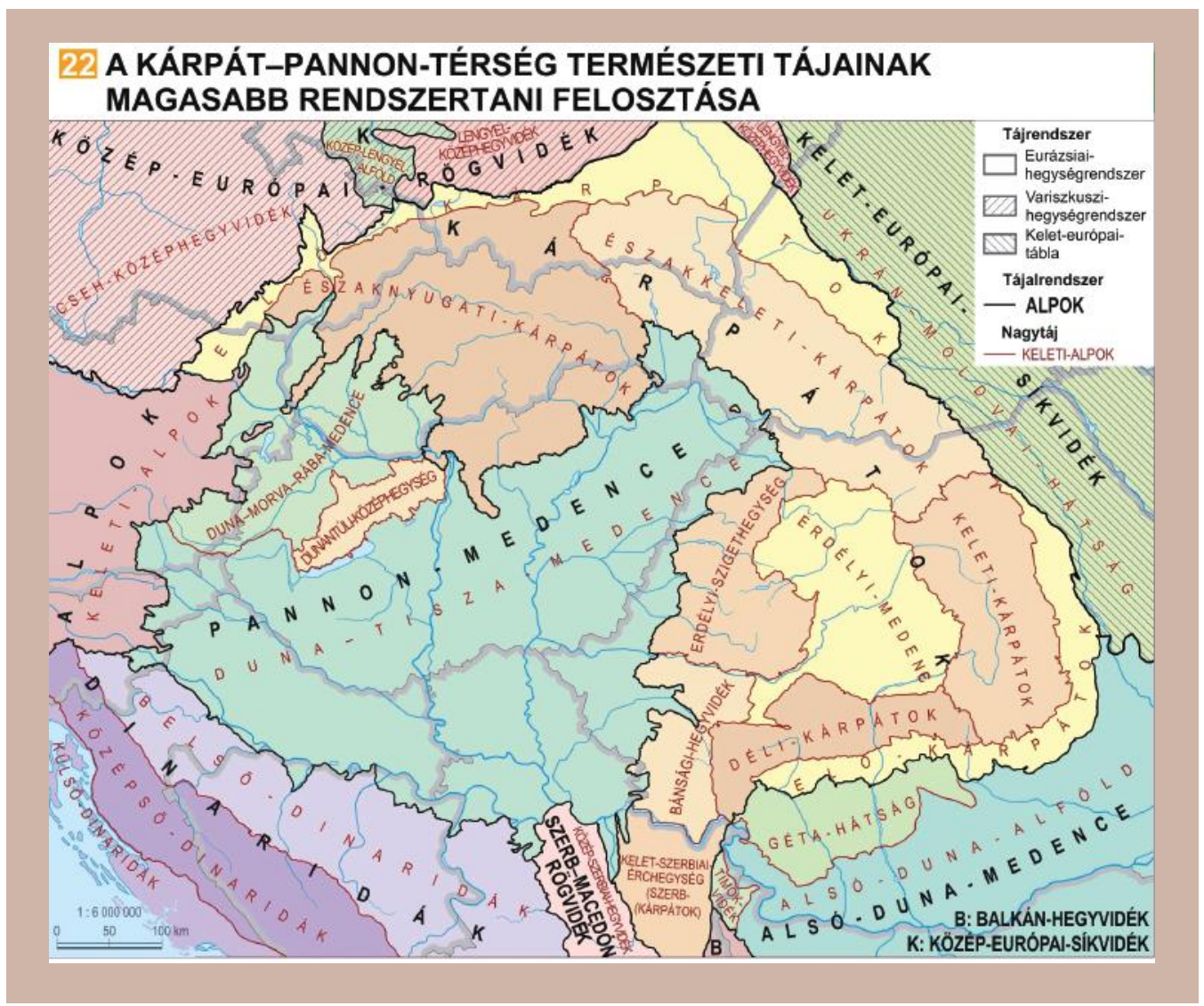

1. ábra. „A Kárpát-Pannon-térség természeti tájainak magasabb rendszertani felosztása” címü térkép a „Magyarország Nemzeti Atlasza” sorozat „Természeti környezet” kötetének „Tájak” fejezetéböl

(www.nemzetiatlasz.hu)

lépcsőkhöz. Mivel a nemzeti atlasz szerkesztői fontosnak tartották, hogy a hazai taxonómiai rendszer harmonizáljon az európai táiföldrajzi beosztással, ezért óhatatlanul átalakult, bővült a korábban használt 4 fokozatú nagytáj - középtáj - kistájcsoport - kistáj hierarchikus rendszer.

\section{Korábbi nagytájaink helye az új taxonómiai rendszerben}

Kétségtelen, hogy részletes magyarázatot igényel, egyszersmind az oktatásban - különösen az általános és középiskolákban - nehézséget okoz, hogy a hegyvidék és a medence eltérő hierarchizáltsága miatt hazánk két középhegysége más taxonómiai szintre került. 
Hasznos viszont, hogy a rendszer megvilágítása kiváló alkalmat nyújt az egész Kárpáttérségben történő gondolkodás fejlesztéséhez.

Korábbi nagytájaink hierarchiaszintjeinek jelenlegi különbsége abból adódik, hogy a Kárpátok tájalrendszert felépítő nagytájakon - Északnyugati-, Északkeleti-, Keleti- és Déli-Kárpátok - belül szerepelnek nagytájrészletek, pl. Belső-Északnyugati-Kárpátok, Külső-Északnyugati-Kárpátok, s csak ezután - már a középtájak szintjén - szerepel a mi Északi-középhegységünk. A Pannon-medencét, mint tájalrendszert viszont két nagytájra osztjuk; a Duna-Tisza-medencére, ill. a Duna-Morva-Rába-medencére, előbbi részeként pedig nagytáji besorolással már következik a Dunántúli-középhegység. Itt tehát kevesebb taxonómiai lépcsőre van szükség, míg eljutunk a korábbi nevezéktan nagytáji szintjéig.

A többi - eddig nagytájnak nevezett - tájegységünk, az Alföld, a Kisalföld, az Alpokalja és a Dunántúli-dombság nagytájrészlet besorolást kapott, tehát a nagytáj Dunántúli-középhegység és a középtáj Északi-középhegység közötti hierarchiaszintre kerültek (1. táblázat).

A fenti felsorolásból látható, hogy az új nevezéktani rendszerben nagytájrészletként nagyobb súlyt kap az Alpokalja kifejezés, ami eddig középtájként szerepelt a taxonómiai rendszerben. Az Alpokalja a korábbi „Nyugat-magyarországi peremvidék” területéből 7 kistájra terjed ki, a Középsö-Keleti-Alpok nagytájrészlethez sorolt 2 - nagyobb részben magyarországi - hegység (Soproni- és Kőszegi-hegység) folytatásaként. A Dunától keletre két nagytájrészlet alkotja a hierarchia magasabb szintjét, a Belső-Északnyugati-Kárpátok, valamint az Alföld. Ezzel a nevezéktani változtatással lényegében mindkét nagy hegyvidék, az Alpok és a Kárpátok is megjelenik a hazai térképeken, a két nagytájrészlet nevében.

Következménye a friss tájbeosztásnak, hogy két, alapvetően országhatáron túli nagytájrészlet benyúlik a mai országterületre, így táji rendszerünkben megjelenik a DrávaSzáva-vidék, illetve a Középső-Keleti-Alpok, mint nagytájrészlet, valamint azoknak közép-, illetve kistájnyi nyúlványa, a Dráva-Murai-Alpokalja és a Közép-Dráva-síkvidék, továbbá a már említett Soproni- és a Köszegi-hegység. A Mura és a Dráva menti területek közül az országhatáron belülre esik 3 kistáj; a Kerka-vidék, az Alsó-Mura-sík és a Légrád-Barcsi Dráva-völgy. Az alpi rendszerrészhez történő kapcsolás különösen a Kerka-vidék esetében volt bizonytalan, mert ez a kistáj nagyjából hasonló joggal kerülhetett volna a Dunántúli-dombvidékhez, közelebbről a Zalai-dombsághoz is. 


\begin{tabular}{|c|c|c|c|c|c|c|}
\hline $\begin{array}{l}\text { Tájrendszer } \\
\text { system }\end{array}$ & $\begin{array}{l}\text { Tájalrendszer } \\
\text { subsystem }\end{array}$ & $\begin{array}{l}\text { Nagytáj } \\
\text { province }\end{array}$ & $\begin{array}{l}\text { Nagytáj- } \\
\text { részlet } \\
\text { subprovince }\end{array}$ & $\begin{array}{l}\text { Középtáj } \\
\text { region }\end{array}$ & $\begin{array}{l}\text { Kistájcsoport } \\
\text { microregion- } \\
\text { group }\end{array}$ & $\begin{array}{l}\text { Kistáj } \\
\text { microregion }\end{array}$ \\
\hline $\begin{array}{l}\text { Variszku- } \\
\text { szi-hegy- } \\
\text { ség-rend- } \\
\text { szer } \\
\text { (Hercynian } \\
\text { System) }\end{array}$ & $\begin{array}{l}\text { Közép-euró- } \\
\text { pai-rögvidék } \\
\text { (Central } \\
\text { European } \\
\text { Highlands) }\end{array}$ & $\begin{array}{l}\text { Cseh-közép- } \\
\text { hegyvidék }\end{array}$ & Szudéták & & & \\
\hline \multirow{7}{*}{$\begin{array}{l}\text { Eurázsi- } \\
\text { ai-hegy- } \\
\text { ség-rend- } \\
\text { szer } \\
\text { (Alpine-Hi- } \\
\text { malayan } \\
\text { System) }\end{array}$} & $\begin{array}{l}\text { A. Alpok } \\
\text { (Alps) }\end{array}$ & $\begin{array}{l}\text { A.1. } \\
\text { Keleti-Alpok }\end{array}$ & $\begin{array}{l}\text { A.1.3. } \\
\text { Középső-Ke- } \\
\text { leti-Alpok }\end{array}$ & $\begin{array}{l}\text { A.1.3.1. } \\
\text { Stájer-Elö- } \\
\text { Alpok }\end{array}$ & - & $\begin{array}{l}\text { A.1.3.1.1.1. } \\
\text { Soproni- } \\
\text { hegység }\end{array}$ \\
\hline & $\begin{array}{l}\text { B. Kárpátok } \\
\text { (Carpathians) }\end{array}$ & $\begin{array}{l}\text { B.2. } \\
\text { Északnyuga- } \\
\text { ti-Kárpátok }\end{array}$ & $\begin{array}{l}\text { B.2.2. } \\
\text { Belső-Észak- } \\
\text { nyugati- } \\
\text { Kárpátok }\end{array}$ & $\begin{array}{l}\text { B.2.2.6. } \\
\text { Északi- } \\
\text { közép- } \\
\text { hegység }\end{array}$ & $\begin{array}{l}\text { B.2.2.6.5. } \\
\text { Bükk-vidék }\end{array}$ & $\begin{array}{l}\text { B.2.2.6.5.4. } \\
\text { Bükkalja }\end{array}$ \\
\hline & $\begin{array}{l}\text { C. Pannon- } \\
\text { medence } \\
\text { (Pannonian } \\
\text { Basin) }\end{array}$ & $\begin{array}{l}\text { C.1. } \\
\text { Duna-Mor- } \\
\text { va- } \\
\text { Rába- } \\
\text { medence }\end{array}$ & $\begin{array}{l}\text { C.1.2. } \\
\text { Alpokalja }\end{array}$ & $\begin{array}{l}\text { C.1.2.1. } \\
\text { Kőszeg- } \\
\text { Soproni- } \\
\text { Alpokalja }\end{array}$ & - & $\begin{array}{l}\text { C.1.2.1.1.2. } \\
\text { Soproni- } \\
\text { medence }\end{array}$ \\
\hline & & & $\begin{array}{l}\text { C.1.3. } \\
\text { Kisalföld }\end{array}$ & $\begin{array}{l}\text { C.1.3.7. } \\
\text { Kemenes- } \\
\text { Marcal-vidék }\end{array}$ & $\begin{array}{l}\text { C.1.3.7.2. } \\
\text { Marcal-vidék }\end{array}$ & $\begin{array}{l}\text { C.1.3.7.2.3. } \\
\text { Pápai-sík }\end{array}$ \\
\hline & & $\begin{array}{l}\text { C.2. } \\
\text { Dunántúli- } \\
\text { közép- } \\
\text { hegység }\end{array}$ & & $\begin{array}{l}\text { C.2.1.1. } \\
\text { Bakony-vidék }\end{array}$ & $\begin{array}{l}\text { C.2.1.1. } 2 . \\
\text { Északi- } \\
\text { Bakony }\end{array}$ & $\begin{array}{l}\text { C.2.1.1. 2.2. } \\
\text { Tési-fenn- } \\
\text { sík }\end{array}$ \\
\hline & & $\begin{array}{l}\text { C.3. } \\
\text { Duna-Tisza- } \\
\text { medence }\end{array}$ & $\begin{array}{l}\text { C.3.2. } \\
\text { Dunántúli- } \\
\text { dombvidék }\end{array}$ & $\begin{array}{l}\text { C.3.2.4. } \\
\text { Külsö- } \\
\text { Somogy }\end{array}$ & - & $\begin{array}{l}\text { C.3.2.4.1.3. } \\
\text { Kapos } \\
\text { menti } \\
\text { dombság }\end{array}$ \\
\hline & & & C.3.3. Alföld & $\begin{array}{l}\text { C.3.3.8. } \\
\text { Közép-Tiszai- } \\
\text { síkvidék }\end{array}$ & $\begin{array}{l}\text { C.3.3.8.1. } \\
\text { Közép-Tisza } \\
\text { mente }\end{array}$ & $\begin{array}{l}\text { C.3.3.8.1.1. } \\
\text { Taktaköz }\end{array}$ \\
\hline $\begin{array}{l}\text { Kelet-euró- } \\
\text { pai-tábla } \\
\text { (East } \\
\text { European } \\
\text { Platform) }\end{array}$ & $\begin{array}{l}\text { Kelet-euró- } \\
\text { pai-síkvidék } \\
\text { (East Europe- } \\
\text { an Lowland) }\end{array}$ & $\begin{array}{l}\text { Ukrán-Mold- } \\
\text { vai-hátság }\end{array}$ & $\begin{array}{l}\text { Volhínia-Po- } \\
\text { dóliai-hátság }\end{array}$ & & & \\
\hline
\end{tabular}

1. táblázat. Az európai tájbeosztási rendszer és néhány példaként feltüntetett tájegység (Kivastagitott betükkel az eddig egyenrangúan nagytájaknak nevezett hazai tájegységek; a nevek elötti számok, illetve betük megegyeznek az atlasz 19. és 22. sorszámú térképein található azonositókkal.) 
A kibővült, 7 taxonómiai szintre tagolódott tájbeosztási rendszer egy térképen történő ábrázolása annyira zsúfolttá tenné az atlaszban szereplő térképet, hogy a legfelső kategóriák kontúrjait és neveit melléktérkép formájában egy ún. szövegközi ábra tartalmazza (1. ábra).

A legnehezebben föloldható problémát természetesen az Északi-középhegység elnevezése jelentette. Ezt a megnevezést a trianoni határokkal szigorú keretek közé szorított szemlélet az 1950-es évek végén honosította meg. A hegyvidék az 1936-ban készült, Prinz Gyula által kidolgozott tájbeosztáson Mátraerdőként szerepel, s tény, hogy ennek az elnevezésnek vannak évszázados történelmi (okleveles) előzményei (PrInz Gy. 1936). Jelzés értékü hogy az 1950től több kiadást megélt „Földrajzi térképfüzet” (TAKÁcs J. - BogNáR G.; Tankönyvkiadó, Budapest) lapjain nincs feltüntetve az összefoglaló elnevezés, csak a Börzsönytől a Zemplénihegységig a vonulat egyes tagjai. Az Északi-középhegység kifejezés az 1961-től megjelent „Földrajzi atlasz a középiskolák számára” (szerk. RADó S.) című kiadványban bukkan föl. Az 1990-es években a Mátraerdő megnevezést elevenítette föl HaJdú-MoHa Ros József és Hevesi Attila, az „-erdő” megjelölést alkalmazva más nagyobb hegyvidék esetében is; pl. Biharerdő, Bakonyerdő (ld. Pannon Enciklopédia, Magyarország földje, Karátson D. 1997). Tény, hogy ha eltekintünk az országhatároktól, akkor a szóban forgó középhegység a Kárpátok északi ívének épphogy a legdélebbi vonulata, tehát az Északi-középhegység szlovák oldalról nézve semmiképp sem északi. Ugyanakkor a túl archaikusan hangzó Mátraerdő, Bakonyerdő, Biharerdő elnevezések visszahozását végül is a nemzeti atlasz tájföldrajzi ad-hoc bizottsága nem támogatta. Helyette sokáig a Mátra-Tokaji-hegyvidék, a Dunántúliközéphegyvidék, ill. az Erdélyi-szigethegység elnevezés mellett érveltünk. A Mátra-Tokajihegyvidék megnevezés pártolói úgy gondolták, hogy a „vidék” kifejezés alkalmazása jól utal arra, hogy a területet tágabb értelemben átfogó kifejezésről van szó. Tehát a hegyláncot nem a szélső tagok „tól-ig” megjelölésével, hanem annak a legmagasabb (Mátra) és a legismertebb (Tokaji) két tagjáról nevezzük el. Felmerült még a Börzsöny-Mátra-Tokaji-hegyvidék variáció is, de ezt a bizottság túl hosszúnak találva elvetette. Végül a szakmai közvélemény markáns ellenvéleménye, s nem kis részben az Északi-középhegységnek a köznyelvben rendkívül erősen meggyökeresedett mivolta miatt nem jóérzéssel, de az eddigi elnevezés meghagyása mellett döntöttünk. Elgondolkodtató érv volt az is, hogy az Északi-középhegység megnevezésének módosítása korrekciót kívánt volna az összes iskolai tankönyv, térkép, atlasz esetében, aminek természetesen nem csekély a pénzügyi vonzata. 


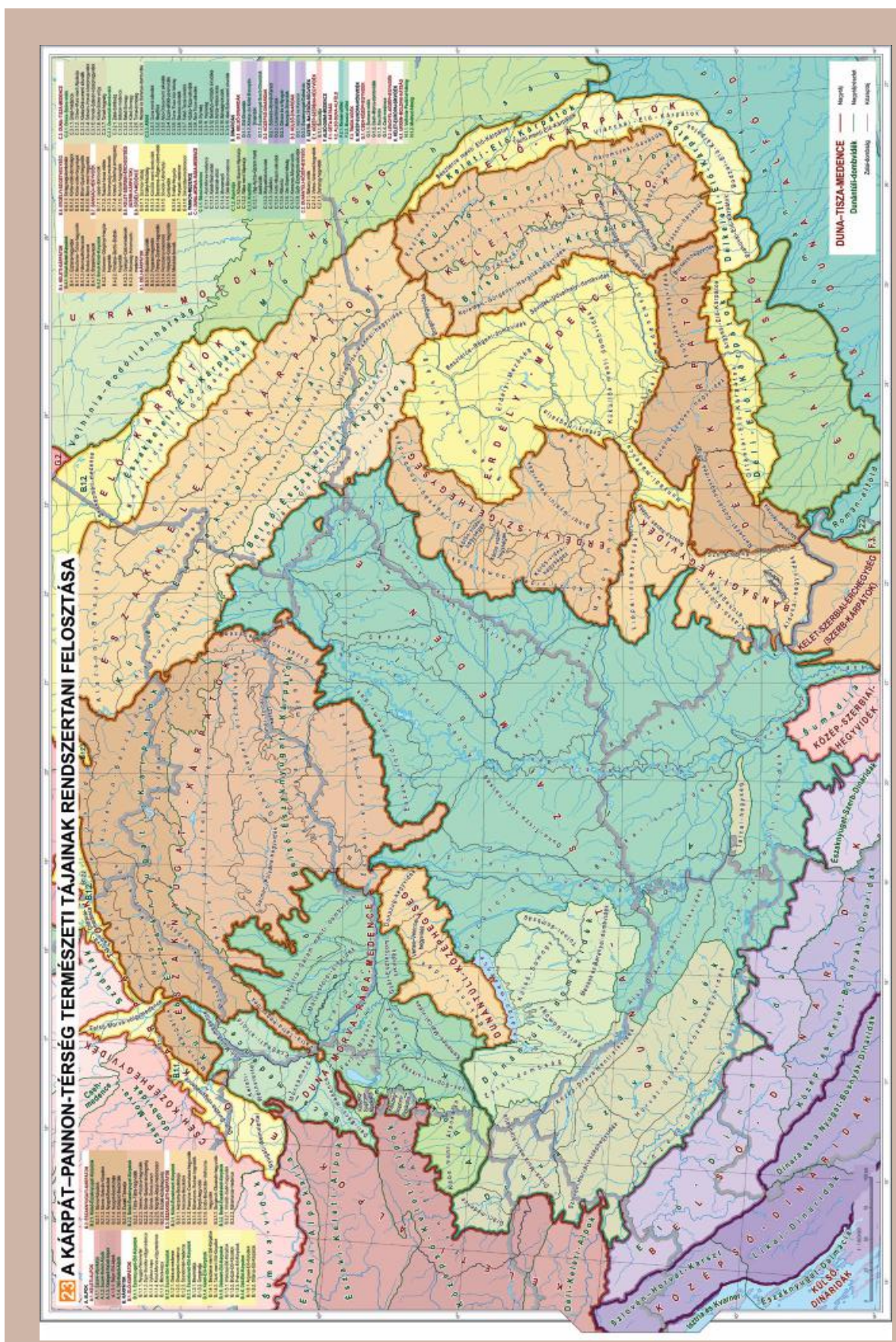




\section{Kistájak és kistájcsoportok}

Összevonásokat alkalmaztunk több dunántúli hegység, ill. dombság kistájainak esetében; pl. a Zselicnél, a Vértesnél, a Budai-hegységnél, önálló kistáj lett viszont pl. a Somló-Devecseri sík és a Felső-Rába-völgy. Nem támogatta azonban a szerkesztői bizottság a Keszthelyi- és a Balatoni-riviéra kistáj, ill. elnevezés megtartását; ezek beolvadtak a mögöttes hegyvidék kistájba. Új kistájcsoport neve kerül a térképre a Medves-Vajdavár-vidék elfogadásával. Az Alsó-Ipoly-völgy ezután a Vág-NyitraGaram menti dombvidék, mint középtáj, és a Kisalföld nagytájrészlet legkeletibb tagja. Ezzel egy újabb történelmi vármegye nevét sikerült megjeleníteni a hazai térképeken. A szintén sokat vitatott Zempléni-szigethegység név ezentúl betagozódik a Tokaji (Zempléni)-hegység kistájba, ami szintén nem a legelegánsabb névadás. A Tokaj fölött magasodó magányos hegyet, amely „úgy áll a mögöttes hegyvidék előtt, mint király a hadsereg élén”, nagyjából azonos gyakorisággal nevezik Kopasz- vagy Nagy-hegynek. Mi a Tokaji (Kopasz)-hegy megnevezést tartottuk a követendőnek. A fenti hegy, illetve hegység a Tokaj-Hegyalja és az Abaúji-Hegyalja elnevezéssel, továbbá a Hegyközzel és a Szerencsi-dombsággal együtt alkotja az Eperjes-Tokajihegység kistájcsoportot.

Nem a legszerencsésebb módon tudtuk megoldani még a Kemeneshát problémáját, az északi Alsó-Kemeneshát ugyanis a Kisalföld, a Felső-Kemeneshát pedig a Zalai-dombság része lett, s így egy másik nagytájrészletbe, a Dunántúli-dombvidékbe kapott besorolást. Ennek oka, hogy a két kistájat együtt sem a Kisalföldhöz, sem az Alpokaljához, sem a Dunántúli-dombvidékhez nem lehet megnyugtató módon elhelyezni, tehát szükségszerủ volt a két rész taxonómiai megosztása.

Hasonló érzékeny pont volt minden korábbi tájbeosztásnál az is, hogy melyik magasabb tájegységhez kerüljön a Tapolcai-medence. Az 1989-es térképen a Keszthelyiés a Balatoni-riviérával együtt a Dunántúli-dombvidékhez került. Mivel ezeknek a kistájaknak a megtartását nem tartottuk indokoltnak, a Tapolcai-medence is átkerült a Dunántúli-középhegyvidék nagytájba. A nagytáj déli határa ugyanakkor a tó északi partvonala, tehát a Balatont, ezt a különleges kistájat a Dunántúli-dombsághoz kapcsoltuk. Sajnos topográfiai okok miatt a Tátika környéki vulkánikus hegycsoportot nem lehetett a Tapolcai-medencéhez kapcsolni, így a geológiai különbözősége ellenére a Keszthelyi-hegység kistáj része lett. 
Feltünhet, hogy a kistájcsoport kategória több nagyobb tájegység - pl. a Dunántúlidombvidék és az Alpokalja - esetében egyáltalán nem jelenik meg, s máshol is több helyen kimarad ez a taxonómiai szint. Ennek az az oka, hogy ezt a hierarchiaszintet a Kárpátoktól levezetett Északi-középhegység esetében egyáltalán nem tudtuk nélkülözni, az alföldi tájak tagolásánál pedig helyenként szintén indokolt volt a kistájcsoport szint beiktatása. Ettől függetlenül igaz, hogy a hierarchikus rendszer elméleti érvekkel legkevésbé alátámasztott kategóriája a 31 kistájcsoport léte. Mit jelent tulajdonképpen a kistájcsoport fogalom, és azon túl, hogy néhol szükség volt még egy hierarchiai szint megnevezésére, mely esetekben indokolt a kistájak bizonyos csoportját összevonni és mely esetekben nem? Ennek a kérdésnek a megválaszolásához jelentős segítséget nyújtott a Mezősi Gábor és Bata Teodóra által kidolgozott módszer, amivel kiszámították a kistájak tulajdonságai között fennálló ún. euklideszi távolságot (Mezősı G. - BATA T. 2011). A többdimenziós skálázás, főkomponens-analízis, a Kruskal-stressz-mérés és a hierarchikus klaszterezés végeredményeképp kialakultak a kistájak bizonyos csoportjai, amelyekre joggal mondhattuk, hogy indokolt egy elkülönült hierarchikus szinten kistájcsoportként lehatárolni.

Helyenként zavart okozott a földrajzi és a néprajzi tájegységek összekavarodása, mint pl. a Göcsej, a Hetés vagy a Jászság stb. esetében. A bizottság következetesen ragaszkodott ahhoz, hogy itt egy természetföldrajzi tájbeosztás elkészítése volt a feladat. Az atlaszsorozat egy későbbi kötetében természetesen lesz néprajzi tájhatárokat feltüntető térkép!

Az országhatár „légiesítésével” a hazai kistájnevek közé bekerült néhány határon túli település neve; pl. Csanád-Aradi-hát, Németújvári-dombság, Röszke-Titeli-sík. A szóban forgó tájak nagyobb része az országhatáron kívül fekszik, a szomszéd országban az adott településsel jelzett elnevezés használatos, a településnek van jól megőrződött magyar neve, emiatt a hazai „csonka” tájrészletnek Balf-Ruszti-dombság helyett más nevet (pl. Fertő-melléki-dombság) adni indokolatlan.

A nevezéktani felülvizsgálat során fontos szempont volt a domborzati fogalmak következetes használata, valamint a nagyságrendi hierarchia érvényesítése, pl. a síkvidék-síkság-sík, illetve hegyvidék-hegység-hegy esetében. A korábbi táji nevezéktanban az is elég sürün előfordult, hogy geomorfológiai fogalmak jelentek meg a tájak nevében, pl. ártér, terasz, hordalékkúp. Ezeket a felszínalaktani típusra utaló szavakat nem tartottuk szükségesnek megtartani. Kivételt tettünk azonban néhány sajátos geomorfológiai kifejezéssel, mint pl. a völgymedence (pl. Rakacai-völgymedence), a hát, hátság, hegyhát (pl. Marcali-hát, Szamos-hátság, Vasi-Hegyhát), valamint a 


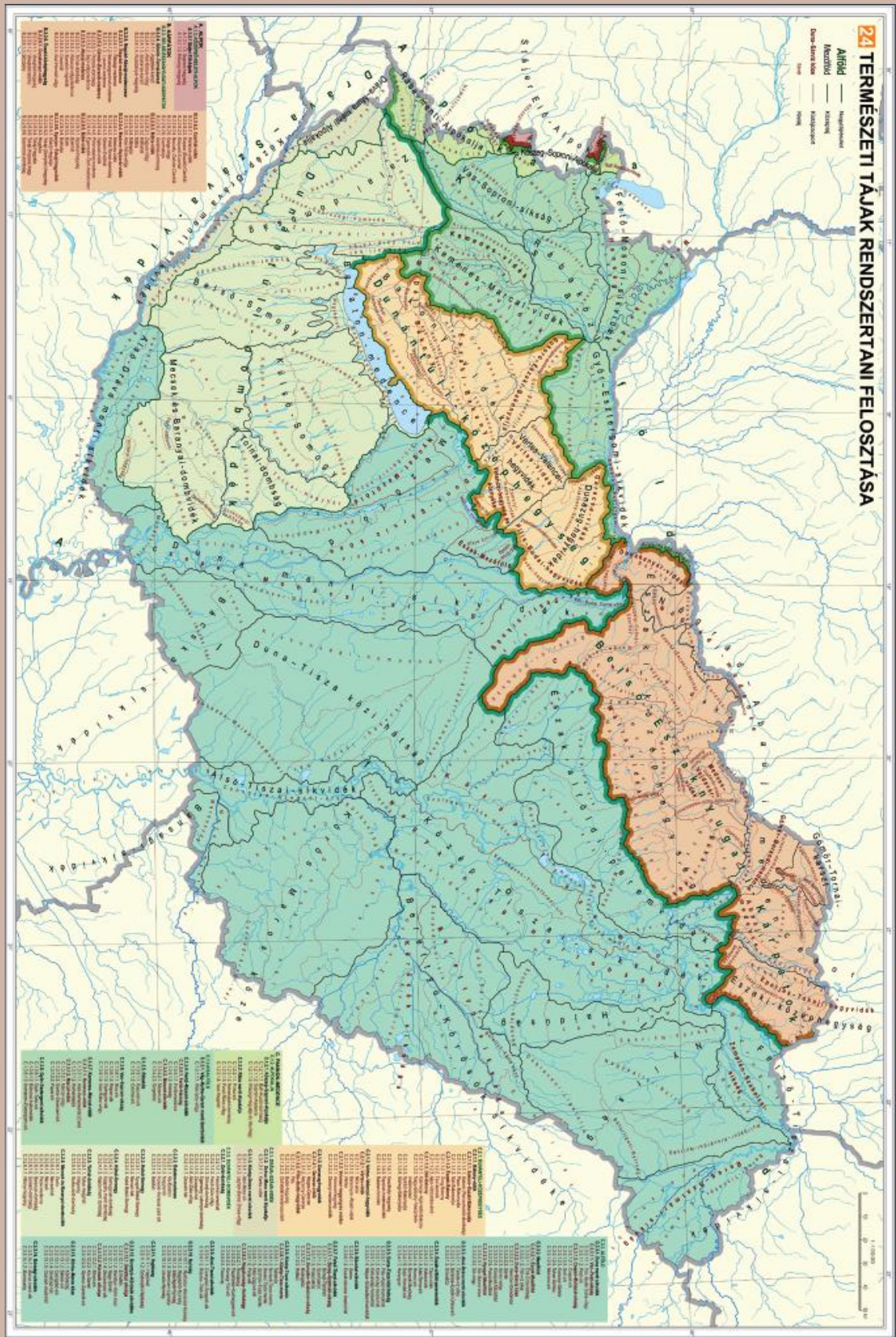


Előző oldal: 3. ábra. A „Természeti tájak rendszertani felosztása (Magyarország)” címü térkép a „Magyarország Nemzeti Atlasza” sorozat „Természeti környezet” kötetének „Tájak” fejezetéböl (www.nemzetiatlasz.hu)

halomvidék (pl. Bábolnai-halomvidék) esetében. Az ad-hoc bizottság erdélyi tagjai feltétlenül megőrzendőnek javasolták néhány hegyvidék „havasként” történő szerepeltetését, pl. Brassói-havasok.

Hasonlóképpen igyekeztünk kerülni a litológiai, vagy kőzettani felépítésre utaló jelzőket is, de ez bizonyos esetekben - főleg síkvidékeinknél - annyira egyértelmüen arculatformáló és elkülönítő jellegü, hogy nem lehetett elhagyni, mint pl. a „löszös” vagy „homokos” jelzőket. Ugyanilyen okok miatt megtartottuk a „karszt” végződésü kistáji neveket, pl. Aggteleki-karszt.

A felülvizsgálat eredményeképpen a középtájak száma 39-ről 37-re csökkent, míg a kistájak száma a számos összevonás eredményeképp az új térképen csak 195, miközben korábban a Balaton nélkül 229 kistájunk volt. Új, ill. hazai térképeinken újonnan megjelenő középtáj lett a Fertő-Mosoni-síkvidék, a Stájer Elő-Alpok, a VágNyitra-Garam menti dombvidék, a Rába-menti Alpokalja, a Bánsági-síkvidék. Több középtájra osztottuk a korábbi Győri-medencét, vagy a korábban Észak-magyarországi medencék néven futó területeket.

Az adatok szerint a legtöbb változás a kistájak esetében történt. A 35 megszűnt kistáj többsége hegyvidéki kismedence, hegylábi előtér, rész-dombvidék volt (pl. Gánti-medence, Sörédi-hát, Által-ér-völgy stb.). Új kistáj lett viszont a Krasznaköz, az Alsó-Rába-völgy, a Gömöri-Erdőhát vagy a Maros-menti sík. Pusztán a számokat nézve tehát kétségtelenül sok esetben változtattunk a kistájak eddigi elnevezésén, de ezt többségében az említett domborzati hierarchia (hegyvidék-hegység-hegy) követése, ill. a geomorfológiai fogalmak részleges kiiktatása követelte meg. Ezen kívül nem találtuk elég kifejezőnek néhány kistáj összetett égtáj szerinti elnevezését sem: pl. Dél-Külsővagy Kelet-Belső-Somogy stb. Ezeknek a kistájaknak más nevet választottunk, mint pl. Kapos menti dombság, Nagyatádi-dombság. Átalakítást igényelt több név esetében az a furcsa helyzet is, hogy a kistájnak nevet adó település nem esett a táj területére! A kistájkataszter 2010. évi kiadásában pl. sem Devecser, sem Veszprém nem a VeszprémDevecseri-árok kistájon belül helyezkedik el. Ezt a tarthatatlan ellentmondást új névadással kiküszöböltük: Ajka-Hajmáskéri-árok. Ezt az alapelvet sem sikerült azonban maradéktalanul érvényesíteni, a Bakony északnyugati részének alsó hegylábi lejtőjét 
Pápai-Bakonyaljának neveztük, jóllehet Pápa külterülete éppen csak eléri a kistáj határát. A korábbi Pannonhalmi-dombság esetében a helyiek által általánosan használt Sokoró elnevezést emeltük a tájnév élére.

\section{Összegzés}

Magyarország új, 1965 és 1989 után sorrendben 3. nemzeti atlaszának megjelentetése lehetőséget adott a hazai természetföldrajzi tájbeosztás felülvizsgálatára is. A legsürgetőbb feladat az volt, hogy a hazai tájbeosztást összehangoljuk a szomszédos országok időközben kiadott atlaszainak tartalmával. Szerencsére a kistájak határai tekintetében az újabb természetföldrajzi kutatások csak viszonylag kevés - és semmiképpen sem több 10 km-es léptékü - határmódosítást javasoltak. Úgy tűnik, hogy ekkora „tévedést” senki nem bizonyított rá az 1989-ben közölt térkép szerzőire. Az összevonásokon és néhány új kistáj kijelölésén túl a most publikált térképen csak kevés számú és csekély nagyságú tájhatár-módosítást tettünk, pl. a Kerka torkolatvidékénél, Illancs DK-i határánál, az Észak-bácskai löszös hát K-i, a Hortobágy DNy-i részén, a Pétervásárai-, a Zsámbéki- és a Tapolcai-medence körvonalainál.

Az ismertetett változtatások azzal a következménnyel is járnak, hogy szakmánk „bestsellere”, a csak néhány éve felújított Magyarország kistájainak katasztere (DövéNYI Z. 2010) kötet is korrekcióra szorul. Ezzel egy kellemetlen róka-fogta-csuka állapotba kerültünk; a térképet változatlanul hagyni csak azért, hogy ne kelljen átírni a kistájkatasztert, nyilvánvalóan nem lehetett, viszont ezek után kötelességünk volna rövid időn belül elkészíteni a kistájkataszter új kiadását.

Végül azt is meg kell mondani, hogy a nemzeti atlaszba került tájbeosztás térképek szerzőinek névsora elég rövid, abban az elhunyt elődökön kívül csupán Csorba Péter, Kocsis Károly, Horváth Gergely és Gábris Gyula, valamint három erdélyi kollega: Bartos-Elekes Zsombor, Imecs Zoltán és Poszet Szilárd neve szerepel, jóllehet kezdetben ennél szélesebb szakmai kört vontunk be a mühely-megbeszélésekbe. Kétségtelen, hogy az atlasz készítése körüli bizonytalanságok, annak meglóduló, majd lelassuló periódusai miatt nem volt idő és lehetőség egy igazán széles körű szakmai egyetértés kialakítására. Ennek ellenére meggyőződésünk, hogy ez a tájbeosztás kiküszöböli elődeinek néhány hibáját, következetesebb felépítésű és korszerűbb szemléletű, mint elödei voltak. 


\section{Irodalom}

DövÉNYi Z. (szerk.) 2010: Magyarország kistájainak katasztere. - MTA FKI, Budapest. 212 p.

FARAGó I. 2014: Földrajzi nevek. - Egyetemi jegyzet. ELTE, Budapest. 366 p.

Hajdú-Moharos J. - Hevesi A. 1997: A Kárpát-Pannon térség tájtagolódása. - In: Karátson D. (főszerk.): Magyarország földje: kitekintéssel a Kárpát-medence egészére. Kertek 2000 Kiadó, Budapest. pp. 274-284. Kocsis K. (főszerk.) 2018: Magyarország Nemzeti Atlasza. 2. kötet: Természeti környezet. Magyar Tudományos Akadémia, Csillagászati és Földtudományi Kutatóközpont, Földrajztudományi Intézet, Budapest. 188 p.

Mezősı G. - BATA T. 2011: A földrajzi tájak határai. - Földrajzi Közlemények 135. 1. pp. 33-43.

Prinz Gy. 1936: Magyarország tájrajza. - In: Prinz Gy. - Cholnoky J. - Teleki P. - Bartucz L.: Magyar föld, magyar faj I. Magyar földrajz. Királyi Magyar Egyetemi Nyomda, Budapest, 395 p. 